\title{
Enterostomy Site
}

National Cancer Institute

\section{Source}

National Cancer Institute. Enterostomy Site. NCI Thesaurus. Code C122645.

A surgically created external opening into the intestine. 